\title{
The Expression of Property Concepts in Etulo
}

\author{
Chikelu Ihunanya Ezenwafor \& Inyani Adams \\ http://dx.doi./org/10.4314/ujah.v20i1.5
}

\begin{abstract}
Property concepts refer to properties, qualities or characteristics of referents (Thompson 1988). In many languages, there seems to be a correspondence between the expression of property concepts and the adjective category. There are however languages that express property concepts via means other than the adjective category. This paper examines the means by which property concepts are expressed in Etulo. It is observed that property concepts in Etulo are expressed by qualificatives. Etulo qualificatives subsume a small class of adjectives, a subset of verbs and nouns, and a class of ideophones. We adopt Dixon's (2004) typological framework in establishing a distinct category of adjectives in Etulo.
\end{abstract}

\subsection{Introduction}

The adjective is often cited as one of the major lexical categories in the world's languages next to nouns and verbs. There are however, languages for which claims are made on the absence of a distinct adjectival class; languages such as Korean (Martin 1992, Yu 1998), and Lao (Enfield 2004). Some of these claims remain controversial (see Dixon 2004). For languages in which there is an indisputable adjective class, a variation in the size of the class is observed. Some languages have a relatively large and open class while others have a small and closed class. One of the features of many Niger Congo languages is the limited number of pure (underived) adjectives that they possess. Welmers (1973) states 
that "In almost all Niger Congo languages which have a class of adjectives, the class is rather small, and many concepts expressed by adjectives in European languages are expressed by other kinds of constructions using noun, verb or both". Igbo for instance has about eight antonymic pairs of adjectives. In Ewe, only five simple adjectives are attested (Ameka 2002). Other Niger Congo languages like Jukun and Edo lack a separate adjectival class (cf. Welmers 1973, Omoruyi 1986). In Jukun, qualificatives are derived from verbs by reduplication while Edo employs the use of adjectival verbs. The existence of verb-like and/or noun-like adjectives is not peculiar to Niger Congo languages. Genetti and Hildebrandt (2004) distinguish between pure adjectives and verblike adjectives in Manange (a Tiberto-Burman language). Fiona (2004) identifies a set of adjectival verbs which she distinguishes from non-adjectival verbs in Wolof (an Atlantic language spoken in Senegal).

'Qualificatives' as used here covers a wide range of categories that denote property concepts. These categories include a small class of adjectives, a subset of stative verbs, ideophones and a small class of nouns. Since Etulo has few adjectives, it relies largely on other categories to express typical adjectival functions. The rest of the paper is structured as follows: $\$ 2.0$ gives a brief ethnolinguistic information on Etulo, $\S 3$ establishes the adjective class using language internal criteria in conjunction with the typological criteria proposed by Dixon (2004) for identifying an adjectival class, $\$ 4$ discusses the subset of verbs used as qualificatives, $\$ 5$ discusses the use of ideophones and nouns in expressing property concepts, §6 gives a semantic characterization of qualificatives and makes a distinction between adjectives and adjectival verbs, $\$ 7$ discusses the expression of degree in relation 
to property concepts and further examines the use of qualificatives with the intensifier saan. This is followed by the conclusion in $\S 8$.

The data for this research were elicited from language consultants who are native speakers of the Etulo language.

\subsection{Background Information}

Etulo is classified as an Idomoid language of the Benue Congo subgroup of the Niger Congo language family. It is a minority language spoken in some parts of Benue and Taraba states in Nigeria. This study focuses on the variety spoken in the Etulo speech community of Buruku LGA in Benue state. It is relatively under described and has yet no generally accepted standard variety and orthography. The data used here are therefore represented using the International Phonetic Alphabet. Etulo coexists alongside some other languages like Tiv, Hausa, Idoma, Igede etc. which are all spoken in Benue state and are more dominant. Etulo native speakers are mostly bilingual.

\subsection{The Typological Criteria}

From a purely semantic point of view, adjectives prototypically denote property concepts which describe nouns. The semantic view however, falls short as a sufficient yardstick for establishing a separate class of adjectives since property concepts are notably expressed by other categories such as nouns, verbs or both in some languages. To avoid the likely possibility of analysing the equivalent of English or European languages' adjectives as adjectives in other individual languages, one needs to adopt language specific criteria (which may be semantic, phonological, or morpho-syntactic) in identifying a class of adjective for each language. In Hausa (a Chadic language) for instance, adjectives are 
syntactically defined by their use as nominal modifiers or predicators, in addition to the semantic criterion (cf. Newman 2000). In Manange, simple adjectives are morphologically distinguished from some other categories for their lack of inflectional or derivational morphology and syntactically, for their attributive function and ability to occur in a complement clause (cf. Genetti and Hildebrandt 2004).

Dixon (2004) puts forward a typological framework for establishing adjective as a distinct category. He proposes sets of semantic categories for the adjectival class namely, the core and peripheral semantic types. The core semantic type includes four semantic terms (dimension, age, value, and colour) and is associated with languages that have a small adjective class. The peripheral semantic type includes semantic terms such as physical property, human propensity, speed, difficulty, similarity, qualification, quantification, position, and number. This semantic type is associated with medium and large adjective classes. I present below a summary of Dixons typological criteria. A lexical class is considered an adjective class if it

- Denotes some or all of the semantic types (which are based on property concepts)

- Is grammatically distinct from the noun and verb class

- Functions either as a copula complement or intransitive predicate

- Performs attributive function as a nominal modifier

In addition to language internal criteria, I examine how the above characterization applies to the Etulo adjectival category in subsequent sections. 


\subsection{The Adjective Class}

A total of ten adjectives are identified in Etulo. These adjectives are trisyllabic with the phonological structure V-CV-CV. They tend to have a systematic tone pattern with the exception of itsítsî 'short'. Their inherent tones may however, be influenced in grammatical constructions. Etulo adjectives are characterized by a partial reduplication of the consonant and sometimes vowel segments. In some cases, the reduplication is part of the morphological process which derives an adjective from a noun or verb. In other cases, the reduplication is not linked to a derivational process. Four Etulo adjectives are derived in this way. They include the three adjectives of color ómúmá 'red', óndzúndzé 'white', ómbímbi 'black' and ómgbümgbē 'young'. In table 1, I give a list of the ten adjectives, their reduplicated segments and the words from which they are derived.

\section{Table 1.0}

\begin{tabular}{|c|c|c|}
\hline Adjectives & $\begin{array}{l}\text { Reduplicated } \\
\text { Segments }\end{array}$ & Derived from \\
\hline ómúmá 'red' & $/ \mathrm{m} /$ & $\begin{array}{l}\text { má 'be ripe (be } \\
\text { fair)' }\end{array}$ \\
\hline ómbímbí & $/ \mathrm{mbi} /$ & úmbí 'dirt' \\
\hline óndzúndzé 'white' & $/ \mathrm{ndz} /$ & úndzé 'white \\
\hline $\begin{array}{l}\text { ómgbūmgbē } \\
\text { 'young/small' }\end{array}$ & $/ \mathrm{mgb} /$ & òmgbé ‘small' \\
\hline 'new' & /f/ & \\
\hline 'good' & $/ \mathrm{s} /$ & \\
\hline òbúbé & $/ \mathrm{b} /$ & \\
\hline ókwúkwó & $/ \mathrm{kw} /$ & \\
\hline 'short' & $/ \mathrm{tsi} /$ & \\
\hline ògbùgbè & $/ \mathrm{gb} /$ & \\
\hline
\end{tabular}




\subsubsection{Adjectives in attributive function}

Etulo adjectives can function as nominal modifiers. In attributive function, they may precede or follow the modified noun. Below are some examples of adjectives in attributive function:
1) ǹgísè ògbùgbè
- $\quad$ ògbùgbè ǹgísè
'old person' person old old person

2) ajàtù ókwúkwó

- ókwúkwó ájàtù

'a big car'

car big

big

car

3) àbù ìtsìtsî
gown short

$$
\begin{array}{cl}
\text { ìtsítsí } & \text { àbù } \\
\text { short } & \text { gown }
\end{array}
$$

4) ùnwô osùsè

- òsùsè ùnwô good thing

thing good

òùifè ajàtù new car

car new

ómbímbí úndô 'black goat'
black goat

7) ùndò óndzúndze óndzúndzé úndô 'white goat' goat white white goat

\subsubsection{Adjectives in Predicative Function}

Etulo adjectives are characterized by their ability to function as complements in a copula construction. The structure is represented as (CS) COP CC where CS which is the copula subject may be omitted. This applies to contexts where the subject is the $3 \mathrm{SG}$ 
pronoun with [-animate] feature. The following examples are illustrative:

8) òdzú nâ lì ókwúkwó house that $\mathrm{COP}$ big

'That house is big'

9) lì ómbímbí

COP black

'It is black'

10) àjàtù ḿgbí ánî lì òfùfê

car POSS 1SG COP new

'My car is new'

Most adjectives may function as a predicate in a relative clause. In such constructions, they are preceded by the relative marker and the copula as shown in (11) and (12).

11) àbù nwí lì ìtsítsî gown REL COP short

'A gown that is short'

12) òngîâ nwú lì òbùbè woman REL COP bad

'A woman that is bad'

\subsection{Verbs as Qualificatives (Adjectival Verbs)}

The adjectival verbs are a subtype of semantically intransitive predicate which denotes property concepts. In fact, most property concepts in Etulo are expressed by this group of verbs. As with other verbs, adjectival verb roots begin with a consonant or syllabic nasal but never with a vowel. They also take the 
nominalizing vowel prefix in formation of the infinitive verb form. Below is a list of adjectival verbs in Etulo:

Table 2.0

\begin{tabular}{|c|c|c|c|c|c|}
\hline \multicolumn{2}{|c|}{ CV (V) } & \multicolumn{2}{|r|}{$\mathrm{NCV}(\mathrm{V})$} & \multicolumn{2}{|c|}{ CV(N)CV } \\
\hline $\begin{array}{l}\text { nwó̄̄ } \\
\text { dry’ }\end{array}$ & 'be & nidéc $\bar{\varepsilon}$ & 'be tired' & mámā & 'be sour' \\
\hline $\begin{array}{l}\text { má } \\
\text { ripe' }\end{array}$ & 'be & m̀gbò & 'be full' & $\begin{array}{l}\text { gígíe } \\
\text { sharp', }\end{array}$ & 'be \\
\hline $\begin{array}{l}\text { fìù nfî̀à } \\
\text { sweet’ }\end{array}$ & 'be & ǹdù & 'be dirty' & $\begin{array}{l}\text { sùndô } \\
\text { heavy', }\end{array}$ & 'be \\
\hline $\begin{array}{l}\text { fiúú ńfiú } \\
\text { fat' }\end{array}$ & 'be & & & dútsà & 'be heavy' \\
\hline $\begin{array}{l}\text { fiùu ńfié } \\
\text { strong' }\end{array}$ & 'be & & & $\begin{array}{l}\text { túntó } \\
\text { long/far' }\end{array}$ & \\
\hline $\begin{array}{l}\text { jí ujjù } \\
\text { cold' }\end{array}$ & "be & & & $\begin{array}{l}\text { tímbī } \\
\text { bad/ugly' }\end{array}$ & \\
\hline $\begin{array}{l}\int \text { é } \\
\text { big', }\end{array}$ & be & & & $\begin{array}{l}\text { tíjî̀ } \\
\text { good, }\end{array}$ & 'be \\
\hline $\begin{array}{l}\text { núnว̀ } \\
\text { bitter' }\end{array}$ & 'be & & & lúmā & 'be fair' \\
\hline $\begin{array}{l}\text { gì̀̀ngì̀̀̀ } \\
\text { small' }\end{array}$ & be & & & lúmbī & 'be dark' \\
\hline $\begin{array}{l}\text { kíc } \\
\text { old' }\end{array}$ & 'be & & & $\begin{array}{l}\text { sùmsè } \\
\text { beautiful' }\end{array}$ & \\
\hline & & & & kpókó & 'be hard' \\
\hline & & & & Jígbô & 'be tall' \\
\hline & & & & Jímbí & 'be dirty' \\
\hline & & & & $\begin{array}{l}\text { tsídzâ } \\
\text { dirty' }\end{array}$ & \\
\hline
\end{tabular}


These verbs function as the sole predicate in a semantically intransitive construction. At the syntactic level, two main argument slots (subject and object) are filled by nouns. The object position is occupied by the nominal complement which specifies the full meaning of the verb. The syntactic frame of adjectival verbs is represented as NP V (Nominal complement). Thus, in intransitive predicate constructions, Etulo may superficially retain the SV (O) basic word order. Many adjectival verbs are compatible with tenseaspect morphemes (the future marker $k a$, progressive marker $l e$, habitual marker $l i$ and the perfect marker $w a$ ) but to varying degrees. ${ }^{1}$ Below are examples of adjectival verbs used in grammatical constructions;

13) ònó éjî fiú ńfíu

mother 1PL be fat fatness

'Our mother is fat'

14) òngì̀ $n \hat{\varepsilon} \quad k$ kí

woman this be old

'This woman is old'

${ }^{1}$ The compatibility of tense -aspect morphemes with adjectival verbs requires further investigation. In comparison with activity verbs, it seems that some TA morphemes receive a different semantic interpretation in occurrence with different groups of verbs. For instance, the progressive morpheme le gives an inceptive meaning with at least some adjectival verbs rather than a progressive meaning as with most dynamic verbs (Ezenwafor C.I 2017) 
15) ùnwógīē nâ jí ùjù food that be cold cold 'That food is cold'

16) ànwúntò ḿgbí ánî Jímbí

cloth POSS $1 \mathrm{SG}$ be dirty

'My clothes are dirty'

\subsection{Verbs in Attributive Function}

Adjectival verbs may modify the noun in attributive contexts. To function as modifiers, they occur in relative clause constructions or alternatively take the low tone nominalizing prefix $o$ - (see 17-19). In both cases, they are preceded by the modified noun. In a relative clause, the relative markers $n w i$ and $n w u$ are preceded by the modified noun and followed by the adjectival verb. Note that adjectival verbs do not take a prefix when they function as a predicate in a relative clause. Some of the nominalized verbs additionally require a full reduplication of the verb root in attributive function. As illustrated in (17a), the verb $k i \bar{\varepsilon}$ 'be old' which modifies ǹgísè 'person' obligatorily takes the low tone prefix and has its root reduplicated. Some other verbs that require prefixation and reduplication in attributive function include timbi 'be ugly', fimbi 'be dirty', and ìdù 'be dirty'.

17a) n’gísc̀ ò-kíć-kíc

person/man PREF-be old-RED

'An old person'

17b) ǹgísč nwú kíç

person REL be old

'A person that is old' 
18a) ánî kié ígbé ò-sùndô

1SG:SUBJ carry bag PREF-be heavy

'I am carrying a heavy bag'

18b) ánî kié ígbé nwí sùndô

1SG:SUBJ carry bag REL be heavy

'I am carrying a bag that is heavy'

19a) j̀d ò ò-mámā

soup PREF-be sour

'A sour soup'

19b) j̀dò nwí mámā

soup REL be sour

'soup that is sour'

\subsection{Other means of expressing property concepts}

Besides the use of adjectives and verbs, other categories such as a subset of nouns and ideophones may equally denote property concepts. Such nouns include ìmàfà 'youth', òtsé 'sickness', itíng $\bar{a}$ 'anger', èmbùà 'hunger', àdzè 'poverty', ìnwíndà/mnnwàzá 'beauty' Some of these nouns function as copula complements just like adjectives (20a-20b) or as nominal modifiers (20c). Like typical nouns, this subset of nouns are modified by nominal modifiers such as demonstratives, possesives etc.

20a) ò lì m̀mmàfà

3SG COP youth

'She is young 
20b) à dzé àdzè sáān

3PL COP poverty INT

'They are very poor'

20c) ábû lé kì̀ itíngā

2SG:SUBJ PROG do anger

'You are feeling angry'

They also function as nominal modifiers. Consider the following examples:

21a) òngîa ìnwíndà

woman beauty

'beautiful woman'

21b) ǹgísè itíngā person anger 'angry person'

Etulo has a class of ideophones which perform a variety of functions. One of these functions is to describe the properties of a noun in constructions. Such ideophones include fèlèfèlè 'silky', tròtrò 'smooth' léngéléngé 'slim', tét ťté 'sound of dripping water', plédédédé 'white', biuиu 'black'etc. In examples (22a) - (22b), the ideophones give a vivid description of the attributes of the NP subjects. When ideophones serve as nominal modifers, they take the nominalizing prefix $o$ - (23a and 23b) Examples:

22a) ìkié ḿgbí ánî lè trètrè head POSS $1 \mathrm{SG}$ is IDEO 'My head is bald' 
22b) ànwúntò $n \hat{\varepsilon} \quad$ lè fèlèfèlè cloth this is IDEO 'This cloth is silky'

23a) ànwúntò ò-fèlèfèlè cloth PREF-IDEO 'silky cloth'

23b) òngîa ò-léngéĺ́ngé woman PREF-IDEO 'slim woman'

\subsection{Semantic characterization of qualificatives}

Some property concepts are expressed by a subset of qualificatives with the same or similar meaning. The semantic feature of the modified noun informs the use of one form over the other. As an example, the English adjective heavy is expressed by two adjectival verbs namely sundo and dutsa. Inanimate nouns are qualified by sundo while animate nouns are qualified by duntsa. ${ }^{2} \mathrm{~A}$ similar example is with the English adjective beautiful which is denoted by the nouns inwinda [+female], mnwaza [+male] and the adjectival verb sumse [+inanimate]. Additionally, some adjectives tend to have a corresponding adjectival verb. They are listed in the table below;

${ }^{2}$ The verb sundo 'be heavy' may modify the Etulo noun for a human corpse (but then, a human corpse is [-animate]). 
Table 3.0

\begin{tabular}{|c|c|c|c|}
\hline \multicolumn{2}{|l|}{ Adjectives } & \multicolumn{2}{|c|}{ Adjectival verbs } \\
\hline òsùsè & 'good' & tífî & 'be good' \\
\hline òbúbé & 'bad' & tímbī & 'be bad' \\
\hline ókwúkwó & 'big' & Jé & 'be big' \\
\hline ómbímbí & 'black' & lúmbī & 'be dark' \\
\hline ómúmá & 'red' & lúmā & 'be fair/red' \\
\hline ògbùgbè & 'old' & & 'be old' \\
\hline ómgbúmgbé & 'small' & gì̀ ǹgì̀ & 'be small' \\
\hline
\end{tabular}

According to Dixon's (2004) proposition, the peripheral semantic types are associated with the medium and large class adjective while the four core semantic types are associated with both small and large adjective classes. It is observed that all of ten identified adjectives in Etulo belong to the core semantic type while adjectival verbs are grouped in both core and peripheral semantic types $^{3}$ (see table 3.1). Some adjectives form antonymic pairs ; for instance osuse 'good' and obube 'bad', ofufe 'new' and ogbugbe 'old', ombimbi 'black' and ondundze 'white'.

\section{Table 3.1}

\begin{tabular}{|l|l|l|lr|}
\hline $\begin{array}{l}\text { Semantic } \\
\text { Type }\end{array}$ & \multicolumn{1}{|c|}{ Adjectives / } & $\begin{array}{l}\text { Adjectival } \\
\text { Verbs }\end{array}$ & Comments \\
\hline Dimension & omgbumgbe & $\begin{array}{l}\text { tunto 'be } \\
\text { 'small', Je 'be }\end{array}$ & $\begin{array}{l}\text { Dimension } \\
\text { denoted }\end{array}$ & $\begin{array}{r}\text { by } \\
\text { longers }\end{array}$ \\
\hline
\end{tabular}

${ }^{3}$ Five out of thirteen semantic types proposed by Dixon are represented in the table 3.1. The first four are core semantic categories while the last belong to the peripheral semantic category. 


\begin{tabular}{|c|c|c|c|}
\hline & itsitsi 'short'. & $\begin{array}{l}\text { 'be tall', fiu } \\
\text { nfiu 'be fat', } \\
\text { gic ngic 'be } \\
\text { small', langa } \\
\text { langa 'be } \\
\text { slim' }\end{array}$ & $\begin{array}{l}\text { both classes. } \\
\text { The adjectives } \\
\text { form no } \\
\text { antonymic pair. }\end{array}$ \\
\hline Age & $\begin{array}{l}\text { ogbugbe 'old', } \\
\text { ofufe 'new' }\end{array}$ & kic 'be old' & $\begin{array}{l}\text { The adjectives } \\
\text { form an } \\
\text { antonymic pair. } \\
\text { The adjectival } \\
\text { verb describes } \\
\text { both animate } \\
\text { and inanimate } \\
\text { nouns unlike } \\
\text { ogbugbe which } \\
\text { as stated earlier } \\
\text { has a [-animate } \\
\text { feature] }\end{array}$ \\
\hline Value & $\begin{array}{l}\text { osuse 'good', } \\
\text { obube 'bad' }\end{array}$ & $\begin{array}{l}\text { tifi 'be good', } \\
\text { timbi 'be bad' }\end{array}$ & $\begin{array}{l}\text { The adjectives } \\
\text { have } \\
\text { corresponding } \\
\text { adjectival verbs } \\
\text { and can form } \\
\text { an antonymic } \\
\text { pair. }\end{array}$ \\
\hline Colour & $\begin{array}{l}\text { ondzunde } \\
\text { 'white', } \\
\text { ombimbi } \\
\text { 'black', omuma } \\
\text { 'red' }\end{array}$ & & $\begin{array}{l}\text { These are the } 3 \\
\text { basic colour } \\
\text { terms in Etulo. } \\
\text { Other colour } \\
\text { terms such as } \\
\text { green is derived }\end{array}$ \\
\hline
\end{tabular}




\begin{tabular}{|l|l|l|l|}
\hline & & $\begin{array}{l}\text { from the word } \\
\text { for a leaf. }\end{array}$ \\
\hline $\begin{array}{l}\text { Physical } \\
\text { property }\end{array}$ & $\begin{array}{l}\text { timbi 'ugly' } \\
\text { mama 'be } \\
\text { sour', na ons } \\
\text { 'be bitter', } \\
\text { ma 'be ripe', } \\
\text { ndec 'be } \\
\text { of this category } \\
\text { are adjectival } \\
\text { verbs. } \\
\text { tired', nwos } \\
\text { 'be dry', }\end{array}$ \\
& $\begin{array}{l}\text { Jimbi 'be } \\
\text { dirty', gigie } \\
\text { 'be sharp' }\end{array}$ \\
& sundo 'be \\
& heavy', \\
& mgbuo 'full' \\
& etc. \\
\hline
\end{tabular}

\subsection{Differentiating between Adjectives and Adjectival Verbs}

As stated earlier, both categories share in common their ability to denote property concepts. They however, differ in their phonological, morphological and syntactic characterization. Just like most nouns, adjectives commence with a vowel while adjectival verbs begin with a consonant. Both may begin with the syllabic nasal $(/ \mathrm{m} /$ and $/ \mathrm{n} /)$. Only adjectival verbs and ideophones may take the low tone $\dot{o}$ - prefix. Adjectives and adjectival verbs are characterized by reduplication. With the former, this reduplication is partial and lacks an identifiable semantic denotation. With the latter, reduplication is full and only occurs when the relevant (indeed few) adjectival verbs are in attributive function. Most adjectives are classified as core semantic types 
while adjectival verbs may be grouped in both core and peripheral semantic categories. Adjectives serve as copula complements while adjectival verbs function as intransitive predicates which may take nominal complements. Their differences and similarities are further summarised in table below:

\section{Table 4.0}

\begin{tabular}{|l|l|l|}
\hline Features & Adjective & \multicolumn{1}{|c|}{ Adjectival Verb } \\
\hline $\begin{array}{l}\text { Occurs in attributive } \\
\text { function }\end{array}$ & Yes & $\begin{array}{l}\text { Yes (but only in a } \\
\text { relative clause or by } \\
\text { taking a nominalizing } \\
\text { prefix) }\end{array}$ \\
\hline As copula complement & Yes & No \\
\hline As intransitive predicate & No & Yes \\
\hline $\begin{array}{l}\text { Is morphologically } \\
\text { marked }\end{array}$ & No & Yes \\
\hline $\begin{array}{l}\text { Undergoes } \\
\text { reduplication }\end{array}$ & $\begin{array}{l}\text { Yes } \\
\text { (partial) }\end{array}$ & Yes (full) \\
\hline $\begin{array}{l}\text { Is prenominal in } \\
\text { attributive function }\end{array}$ & $\begin{array}{l}\text { Yes } \\
\text { (optional) }\end{array}$ & No \\
\hline Begins with a vowel & Yes & No \\
\hline $\begin{array}{l}\text { Occurs in a relative } \\
\text { clause }\end{array}$ & $\begin{array}{l}\text { Yes } \\
\text { (not all) }\end{array}$ & Yes \\
\hline
\end{tabular}

\subsection{Expression of Degree}

Degree is expressed via the process of verb serialization using the verb $\eta a$ 'surpass'. This applies to both adjectives and adjectival verbs. In the comparative constructions exemplified below, the verb $\eta a ̀$ co-occurs with the copula $l i$ and the adjective òfüfê 'new' in (24a) and with the adjectival verb gigie 'be sharp' in (25a). For 
the superlative construction, $\eta a$ is used in combination with $d u u$ 'all' (see 24b and 25b). The position of the verb $\eta a$ in relation to the adjectival verb is post verbal. With copula constructions (comprising of the copula and adjective), it is preceded by the copula and adjective. There are however, few instances of superlative constructions where $\eta a$ may precede both the copula and adjective. In (24c) for instance, the occurrence of the superlative marker is preverbal ${ }^{4}$.

24a) àjàtù ḿgbí àdì lì òfùfé yà mégbí ánî car POSS PN COP new surpass POSS 1SG 'Adi's car is newer than mine'

24b) àjàtù ḿgbī ánî lì òfùfé yà dúū car POSS 1SG COP new surpass all 'My car is the newest'

24c) àjàtù ḿgbī ádî yăò lì òfùfễ mì ìgbókò dúū car POSS PN surpass COP new in PN all 'Adi's car is the newest in Gboko'

25a) èbà ḿgbì ìsèsé gígíè yà mugbí ánî knife POSS PN be sharp surpass POSS 1SG 'Isese's knife is sharper than mine'

${ }^{4}$ The superlative marker $\eta a$ is realized as $\eta a o$ in $(24 c)$ where it precedes the copula and adjective. This construction may be realized alternatively as àjàtù ḿgbì ádî lì ơfúfê yà mì ìgbókò dúu 'Adi's car is the newest in Gboko'. It is still unclear the reason for the alteration of the verb $y a$ to yao 'surpass'. 
25b) èbà mugbī ìsèsé gígíè jà dúū knife POSS PN be sharp surpass all 'Isess's knife is the sharpest'

For the expression of equivalent comparison, Etulo adopts the use of the morpheme dafi 'as/like' as in (26). On the other hand, negative comparison is marked by the morpheme dafi in combination with the negative marker $b a$ as shown in (27)

26) adi fiu nfiu dafi ola

$\mathrm{PN}$ be fat fatness as PN

'Adi is as fat as Ola'

27) adi fiu nfiu dafi ola ba

PN be fat fatness as PN NEG

'Adi is not as fat as Ola

\subsection{Use of the Intensifier sáān with Qualificatives}

Across languages, the adjectival category is characterized as a gradable class, though it is often the case that some adjectives (property concepts) are not gradable. In Etulo, degree modification involves adjectives and adjectival verbs. It is expressed periphrastically with the morpheme (intensifier) sáān. This morpheme bears a high - mid tone. It modifies the adjective and adjectival verb in both attributive and predicative function. Examples (28a) and (28b) illustrate its use with the adjective itsitsî 'short' in attributive context and as a copula complement. In (29a) and (29b), it modifies the adjectival verbs $m a ́$ 'be ripe' and fé 'be big'. The intensifier occurs in the sentence final position in the examples below. 
28a) ìsèsć lì ìtsítsí sáān

PN COP short INT

'Isese is very short'

28b) ìnànì lì ònwè óngîa òsùsè sáān

PN COP child woman good INT

'Inyani is a very good girl'

29a) m̀tsà nâ mà sáān mango that be ripe INT

'That mango is very ripe'

29b) àdì giá ájàtù nwí Jé sáān

PN buy car REL be big INT

'Adi bought a very big car'

\subsection{Conclusion}

From the foregoing, it is evident that property concepts in Etulo are expressed by a distinct small adjective class, a subtype of stative verbs that I call adjectival verbs, a subset of nouns and ideophones. These categories share a core semantic function but differ in their phonological, morphological and syntactic characterization. In comparison with adjectives and adjectival verbs, the nouns and ideophones in descriptive function have restricted possibilities. This expression of property concepts with different categories is not a peculiar feature but is rather atypical for many West African languages. 


\section{Chikelu Ihunanya Ezenwafor}

Department of Linguistics

Nnamdi Azikiwe University,

Awka

ci.ezenwafor@unizik.edu.ng $\&$

\section{Inyani Adams}

Department of Linguistics

Benue State University

inyaniadams87@gmail.com

\section{Works cited}

Ameka, Felix K. The Adjective Class in Ewe: it's Strata and Emergent Nature. A Paper Presented at the International Workshop on Adjective Classes. Research Centre for Linguistic Typology, La Trobe University, Melbourne, August, 2002.

Dixon, R. M. W. Adjective Classes in a Typological Perspective. Adjective Classes: A Cross-Linguistic Typology edited by Dixon R. M. W and Alexandra Y. Aikhenvald, Oxford University Press, 2004, pp. 1-49.

Enfield, N. J. Adjectives in Lao. Adjective Classes: A CrossLinguistic Typology edited by Dixon R. M. W and Alexandra Y. Aikhenvald, Oxford University Press, 2004, pp.323-347.

Ezenwafor Chikelu I. A Grammatical Sketch of Etulo. PhD dissertation, Pisa: Italy, Scuola Normale Superiore, 2017.

Fiona, M. Is there an Adjective Class in Wolof? Adjective Classes: A Cross-Linguistic Typology edited by Dixon R. M. W and 
Alexandra Y. Aikhenvald, Oxford University Press, 2004, pp.242-262.

Genetti, C. \& Hilderbrandt K. A. The Two Adjective Classes in Manage. Adjective Classes: A Cross-Linguistic Typology edited by Dixon R. M. W and Alexandra Y. Aikhenvald, Oxford University Press, 2004, pp. 74-96.

Martin, E. A Reference Grammar of Korean. Tokyo, Japan: The Charles Tuttle Company, 1992.

Newman, P. The Hausa Language. An Encyclopaedic Reference Grammar. New Haven \& London: Yale University Press, 2002.

Thompson Sandra. A Discourse Approach to the Cross Linguistic Category 'Adjective'. Explanations for Language Universals edited by Hawkins. Basil Blackwell, 1988, pp. 167-185

Welmers, E. African Language Structures. Los Angeles: University of California Press, 1973.

Yu, H.K. A study of Korean adjectives. PhD Dissertation. Seoul: Korea, Yensei University, 1998. 